\title{
Working
}

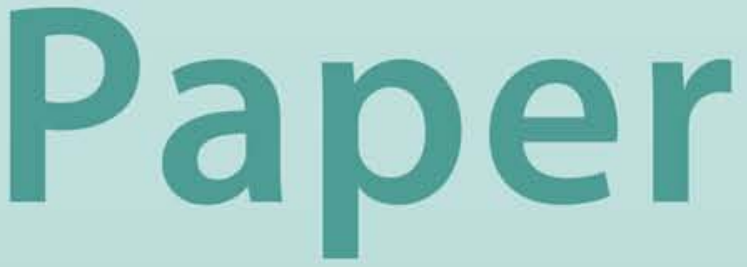




\section{Sovereign Wealth Funds in the Pacific Island Countries: Macro-Fiscal Linkages}

Eric Le Borgne and Paulo Medas 


\title{
IMF Working Paper
}

Fiscal Affairs Department

\section{Sovereign Wealth Funds in the Pacific Island Countries: Macro-Fiscal Linkages}

\author{
Prepared by Eric Le Borgne and Paulo Medas ${ }^{1}$
}

Authorized for distribution by John Thornton

December 2007

\begin{abstract}
This Working Paper should not be reported as representing the views of the IMF. The views expressed in this Working Paper are those of the author(s) and do not necessarily represent those of the IMF or IMF policy. Working Papers describe research in progress by the author(s) and are published to elicit comments and to further debate.
\end{abstract}

This paper looks at the role Sovereign Wealth Funds have played in the Pacific Island Countries in achieving key macro-fiscal policy objectives, namely, protecting the budget from high revenue volatility and strengthening fiscal prospects. Evidence shows that the funds' effectiveness has been hampered by lack of integration with the budget, institutional weaknesses, and inadequate controls. These factors, together with weak asset management, have sometimes led to substantial financial losses and undermined fiscal policy. Funds, if well designed, could be used as a tool to support a sound fiscal framework, but should not be seen as a substitute for fiscal reforms.

JEL Classification Numbers: E61, E62, H11, H60.

Keywords: Sovereign Wealth Funds, Fiscal Sustainability, Fiscal Policy, Stabilization.

Authors E-Mail Addresses: eleborgne@imf.org; pmedas@imf.org

\footnotetext{
${ }^{1}$ We would like to thank Jeffrey Davis, Hali Edison, Rolando Ossowski, Catriona Purfield, John Thornton, Holger van Eden, and Mauricio Villafuerte. An earlier version of the paper served as a background paper for the PFTAC conference on "Trust Funds and Superannuation Funds in the Pacific Island Countries", September 12-13, 2007 in Fiji. The authors are responsible for all remaining errors.
} 
I. Introduction

II. Characteristics of the Pacific Island Economies .........................................................

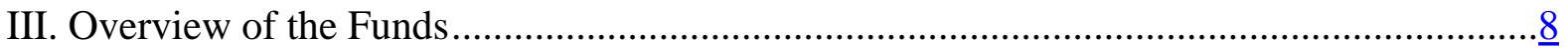

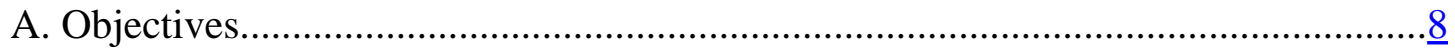

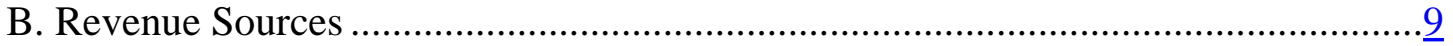

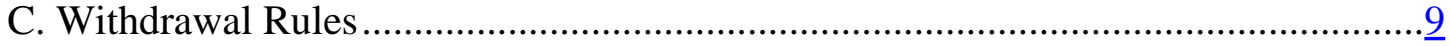

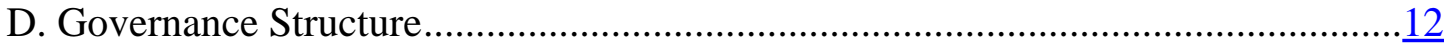

IV. Assessment of the Funds’ Effectiveness...................................................................13

A. Did the Funds Achieve Their Objectives? .................................................... $\frac{13}{17}$

B. A Qualitative Assessment ......................................................................... 17

V. Conclusions and Policy Recommendations ..............................................................22

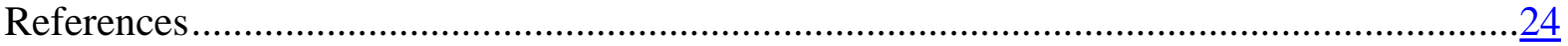

Tables

Table 1. Pacific Island Countries: Sovereign Wealth Funds’ Assets and Public Debt Levels $\underline{20}$ Table A.1. Pacific Island Countries: Basic Geographic, Social, and Economic Indicators ....26

Table A.2. Pacific Island Countries: Central Government Fiscal Indicators..........................27

Table A.3. Operational Rules of Selected Pacific Islands Sovereign Wealth Funds................ 28

Figures

Figure 1. Recent Economic Developments in the Pacific Islands Countries............................ $\underline{5}$

Figure 2. Size and Volatility of Revenue and Grants, 1990-2004 .......................................

Figure A.1. PICs: Revenue Volatility and Sovereign Wealth Funds, 1990-2004..................29

Figure A.2. Structure of the Marshall Islands and Micronesia Sovereign Wealth Funds ........29

Boxes

Box 1. The Withdrawal Structure of Tuvalu's Sovereign Wealth Fund................................11

Box 2. International Experience with Non-Renewable Resource Funds..............................14

Box 3. Expenditure Volatility in the Pacific Island Countries...........................................16

Box 4. State of Public Financial Management in Selected PICs .........................................18 


\section{INTRODUCTION}

Pacific Island Countries (PICs) have a diversified and, in a few cases, long-standing experience with Sovereign Wealth Funds (SWFs). Several PICs have established SWFs in an attempt to help manage the uncertainty and volatility of revenue and achieve a long-term sustainable fiscal path. These funds were set up with revenue from non-renewable sources (Kiribati, Timor-Leste, Papua New Guinea, Nauru), revenue windfalls (Tonga, Tuvalu), or donor contributions (Tuvalu, Marshall Islands, Micronesia, and Palau). In general, the objectives of the funds have been short-term stabilization, long-term savings, and/or longterm budgetary self-reliance.

While the recent public interest in sovereign wealth funds derives largely from the largest funds' potential impact on international financial markets, from a domestic policymaker's viewpoint, a more fundamental question is whether SWFs can be a useful instrument to achieve domestic policy goals. While there is no universally agreed-upon definition of SWFs and their objectives, in general they are considered to be: (i) vehicles to manage public sector financial assets, with or without specific policy objectives; (ii) predominantly engaged in cross-border investments; (iii) having an investment strategy that tends to aim for higher returns than short-term risk-free instruments; and (iv) closely linked to and dependent on foreign exchange inflows, either through external current account surpluses or capital inflows. ${ }^{2}$ SWFs also tend to be classified according to policy objectives; for example, oil countries sometimes create stabilization funds (macro-fiscal management) and/or savings funds (longer-term objectives). In Asia (e.g., Singapore, Korea, China, and Australia) several countries have or just introduced SWFs with a mix of policy objectives, including accumulating long-term savings for future needs (e.g., pension liabilities) and promote national and regional development goals.

The experience of the PICs provides examples of the challenges that (owner) countries are likely to face when setting up sovereign wealth funds. From the macro-fiscal perspective it is important to assess whether the funds help or hinder broader economic policy objectives, and whether they pose potential fiscal risks. Equally important is the need to ensure that the funds have a relatively high degree of transparency in managing (significant) public resources. The experience of the PICs provides some insight into all these issues. ${ }^{3}$

\footnotetext{
${ }^{2}$ This is more evident for natural resource funds (e.g., oil funds), where part of higher natural resource fiscal receipts are transformed into financial assets, but could also involve funds built up from foreign grants and privatization receipts. SWFs could also be created out of domestically-based receipts and fiscal surpluses not directly linked to foreign exchange inflows, but this tends to be unusual.

${ }^{3}$ See IMF (2007), on oil funds, and Johnson-Calari and Rietveld (2007) on sovereign wealth management.
} 
This paper looks at the effectiveness of the PIC funds in meeting the objectives set for them and their impact on fiscal management and outcomes. ${ }^{4}$ In particular, the analysis will focus how well the fund operations were integrated into the overall macro-fiscal policy and whether they helped fiscal management, including tackling the high volatility of revenue. In addition, the paper also examines whether the funds have helped improve asset-liability management and looks at the governance structure of the funds. The paper is organized as follows. Section II describes some key characteristics of PIC economies that have motivated the creation of the funds. Section III provides an overview of the structure of the funds, while Section IV assesses whether they have met their objectives. Finally, based on this assessment, section $\mathrm{V}$ presents the main conclusions and proposes a reform agenda.

\section{ChARACTERISTICS OF THE PACIFIC ISLAND ECONOMIES ${ }^{5}$}

The Pacific Island countries are generally small in terms of population, land area, and GDP (Appendix Table A.1), and are often located thousands of kilometers from major trading centers. Moreover, in several of them the population is spread among many small and farflung islands. These features are known to generate major developmental challenges (Barro and Sala-i-Martin, 1995). The small scale and isolation result in economies with narrow productive sectors based almost exclusively on primary commodities and some tourism services. ${ }^{6}$ In addition, the narrow base for production and exports has exposed these economies to significant terms-of-trade shocks (Easterly and Kraay, 2000), often compounded by natural disasters (especially typhoons, which adversely affect revenues from fishing). Small size and isolation also have hampered economic growth by limiting incentives to accumulate human capital and increasing the cost of doing business. ${ }^{7}$

The economic performance of the PICs has been poor by several measures. Since 1995, average GDP growth in the slowest growing region outside of the PICs was 50 percent higher than that of the PICs; and the emerging Asian countries grew 31/2 times faster than the PICs. At the same time, the PICs have experienced high volatility in real GDP growth.

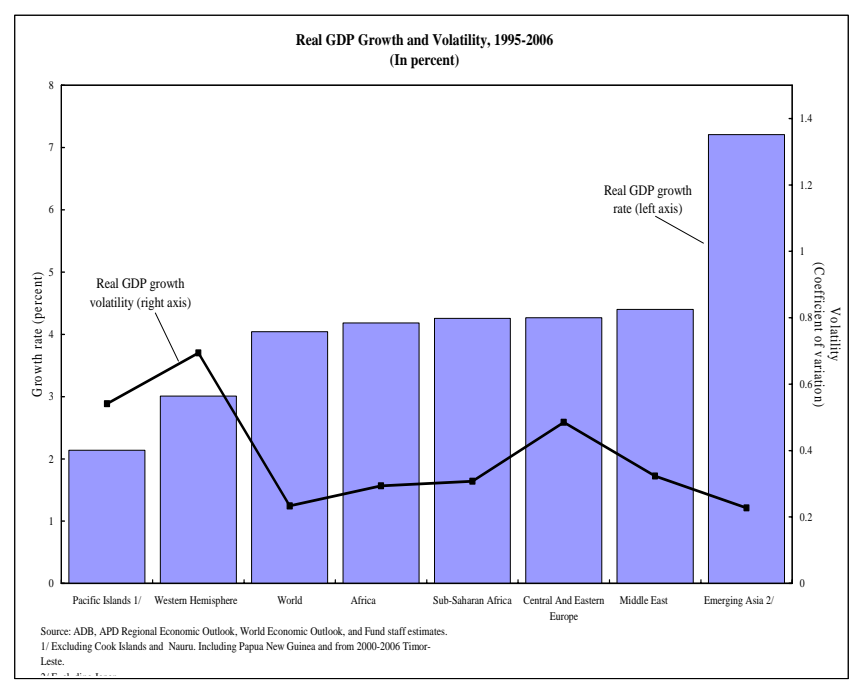

\footnotetext{
${ }^{4}$ The paper is focused on the main funds in the PICs; although several economies have a series of earmarked funds/accounts that fulfill a narrow and specific goal (e.g., Papua New Guinea, Marshall Islands, Tuvalu). In particular, this paper does not look at pension funds.

${ }^{5}$ For the purpose of this paper, Timor-Leste will also be included in the Pacific Island group.

${ }^{6}$ For instance, sugar in Fiji, fish licenses in Kiribati; oil, copper, gold, coffee, and cocoa in Papua New Guinea; and timber, palm oil, and fish in the Solomon Islands (Appendix Table A.1).

${ }^{7}$ Fishing and tourism have been identified in many island economies as potential growth drivers but significant constraints have prevented PICs from fully capitalizing on these opportunities (including geographic isolation, lack of tourism infrastructure, a limited pool of skilled labor, and a growing threat of overfishing).
} 
Figure 1. Recent Economic Developments in the Pacific Islands Countries (2002-2005 average)
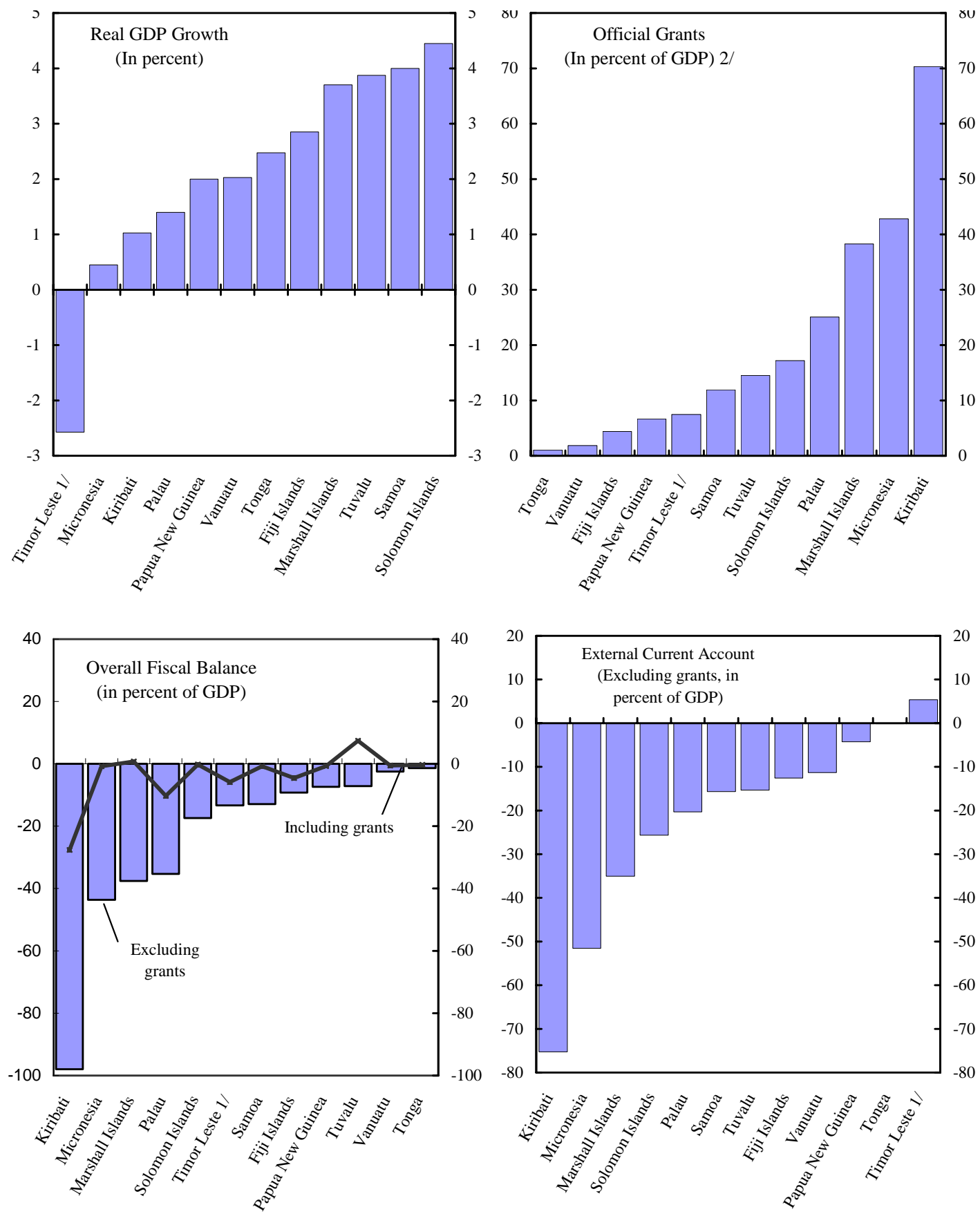

Sources: ADB, APD Regional Economic Outlook, IMF country documents, and Fund staff estimates.

1/ For Timor-Leste, figures refer to non-oil GDP instead of GDP.

2/ Figure for Fiji official grants are based on 2002-04 data.

3/ The Timor-Leste figure also excludes oil revenue.

Low and volatile GDP growth has been accompanied by persistent current account deficits that have been covered mainly by foreign aid and worker remittances (Figure 1) and large swings in fiscal balances (Appendix, Table A.2). For some PICs, these fiscal deficits have, in recent years, become protracted and could ultimately undermine fiscal sustainability and the 
growth prospects. This is particularly the case with Kiribati, which recorded a fiscal deficit of 33 percent of GDP in 2003 and has been running annual deficits in excess of over 20 percent of GDP since then. Micronesia, Palau, the Salomon Islands, and Tuvalu also have experienced large (though shorter lived) fiscal deficits in recent years.

\section{Revenue volatility and sustainability}

Fiscal revenue in the PICs is highly volatile by international standards, particularly with respect to non-tax revenue (for some countries) and grants (for most countries) (Figure 2 and Appendix Figure A.1). For example, in relation to GDP, revenue collection is around 45 percent higher than in European Union (EU) countries, which have the second-highest revenue level, but exhibit more than six times the degree of volatility faced by the EU. Nontax revenue fluctuates widely as its base is subject to large shocks. ${ }^{8}$ Key among these shocks are those affecting fishing license fees, with annual changes in nontax revenue from these fees in Kiribati and Tuvalu, for example, fluctuating by over ten percentage points of GDP from one year to the next (e.g., in 2002-03). Foreign grants account for more than half of total revenue and grants in a number of PICs (including in Kiribati, the Marshall Islands, Micronesia, Palau, and the Solomon Islands). However, over the past five years, several countries have been exposed to annual changes in grant levels of over 10 percentage points of GDP (these include Kiribati, the Marshall Islands, Micronesia, Palau, Samoa, and the Solomon Islands). Tax revenue tends to be relatively more stable, but the size of the taxable private sector is often too small to compensate for the large volatility of other revenue sources. This revenue volatility has resulted in highly volatile expenditures (see section IV).

The tax systems of many PICs are complex (including a multiplicity of tax incentive schemes), sometimes regressive, and reliant on revenue sources that are projected to decline. This is the case, for instance, with trade liberalization initiatives in PICs. These could put pressure, over the medium term, on tariff revenue-countries such as Kiribati, Solomon Islands, and Tonga are most at risk because of their reliance on this revenue source-and will likely require tax reforms (Tonga recently started this process). In addition, tax administration capacity and compliance are often weak, which compounds long-term revenue sustainability concerns. ${ }^{9}$ There is also pressure on non-tax revenue and grants. For example, there are concerns that overfishing is reducing the revenue from fishing license fees in Micronesia, Palau, Tonga and Kiribati, which in the later case declined from 54 percent of GDP in 2001 to 28 percent of GDP in 2006. ${ }^{10}$ In Papua New Guinea (PNG), revenue from the mineral and petroleum sector is projected to decline as a result of tax concessions and resource depletion. In some cases, key donors have also stated their intention to scale down

\footnotetext{
${ }^{8}$ Volatility is estimated as the standard deviation of revenue as a share of GDP, as the objective is to compare the degree of volatility relative to the size of the economy. For example, a sharp decline (increase) in revenue would likely lead to a comparable decline (increase) in expenditure and/or borrowing, both of which would have an impact on the economy.

${ }^{9}$ For example, self-assessment procedures for income taxes are uncommon, audit programs are often not comprehensive, use of single taxpayer identification numbers is sparse, and few countries have modern computer systems.

${ }^{10}$ In part, the volatility in revenue from fishing licenses also reflects exchange rate movements, as the licenses are set in foreign currency (usually U.S. dollars).
} 
budgetary support over time. For example, at the time of inception of the compact agreements (between the U.S. and the Marshall Islands, Micronesia, and Palau), it was envisaged that grants would be gradually reduced as the recipient countries became selfsufficient over time.

Figure 2. Size and Volatility of Revenue and Grants, 1990-2004

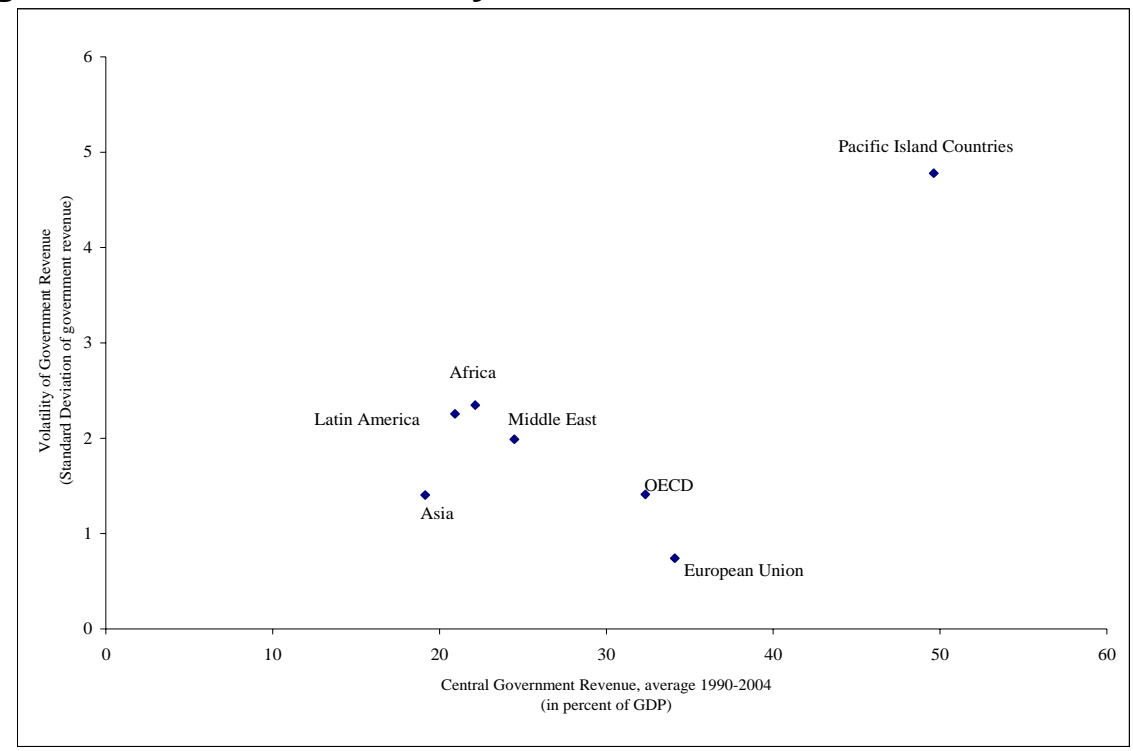

Source: ADB, IMF staff, national authorities.

\section{Large public sectors}

All the Pacific Island economies have large public sectors, but the evidence indicates a relatively low quality of public services. According to the World Bank governance indicators, the PICs perform below average on government effectiveness and controlling corruption. Government expenditure averages around 58 percent of GDP, which is higher than in most other regions of the world (Appendix Table A.2). The composition of spending is mainly geared towards wages and salaries, as public sector employment in some islands accounts for over half of total employment. ${ }^{11}$ In contrast, spending on health, education, and social services is relatively low and often linked to donor involvement. Capital spending is relatively large and is mainly financed by donors.

The relatively large public sectors in part reflect a heritage from the colonial era and, in postindependence years, the large size of foreign aid relative to the domestic economy. In some cases, they may also reflect a demand for "social insurance" given the countries' vulnerability to macroeconomic shocks (e.g., Rodrick, 1998). ${ }^{12}$ Nonetheless, several

\footnotetext{
${ }^{11}$ E.g., in Micronesia, public sector employment accounts for about half of total employment and wages in the public sector are two times higher than in the private sector. Public wages represent more than 40 percent of GDP in Kiribati and between 20-25 percent of GDP in the Marshall Islands, Micronesia, and Palau.

${ }^{12}$ That is, there is a positive correlation between an economy's exposure to international trade and the size of its government. This is often explained by the risk-reducing role that government spending plays in economies exposed to a significant amount of external risk. The relationship between openness and government size is strongest when terms-of-trade risk is highest, which is the case for a few PICs.
} 
countries have sought to put their public finances on a more sustainable basis by implementing difficult structural reforms. For example, starting in 1994, Samoa embarked on a politically difficult but highly effective and sustainable expenditure-led fiscal consolidation (also combined with reforms aimed at improving the efficiency of the tax system and revenue collection) coupled with structural reforms (including privatization). Samoa is now reaping the benefits in the form of higher investment (including FDI), higher and more stable growth, and much improved public finances, including a sharply reduced government debt-to-GDP ratio (from 62 percent of GDP in 2002 to 39 percent of GDP in 2006). Papua New Guinea and the Solomon Islands are also examples of countries that partly reduced vulnerabilities by undertaking a fiscal adjustment (Browne, 2006).

\section{The creation of sovereign funds}

A key challenge for the PICs has been to manage fiscal policy when facing highly volatile and uncertain revenue, and in some cases exhaustible revenue sources (e.g., oil). In addition, most PICS face limited sources of financing. Given their small economic size, PICs have limited or nonexistent domestic financial markets. Often this is coupled with a limited recourse to international capital markets (most rely on financing from multilateral or bilateral donors). To address long-term sustainability concerns and short-term financing constraints, several PICs have opted to establish sovereign wealth funds. The countries with the highest revenue and grants volatility have all established funds (Appendix Figure A.1). However, other countries have addressed these issues by taking a broader, integrated approach to address fiscal vulnerabilities. One successful example is Samoa's macro-fiscal reform program initiated in 1994 and described above.

\section{OVERVIEW OF THE FUNDS}

\section{A. Objectives}

The sovereign funds in the PICs were established mainly as vehicles to accumulate public savings, or to stabilize government revenues, or a mix of both (Appendix Table A.3).

- $\quad$ Savings funds are usually introduced to promote long-term fiscal sustainability and, for countries with non-renewable resources, inter-generational equity. In the region, Timor-Leste's Petroleum Fund (PF) is a typical example of a savings fund, although others have some of the same characteristics (see below).

- $\quad$ Papua New Guinea’s former Mineral Resources Stabilization Fund (MRSF) was the only pure stabilization fund of the region. The MRSF's goal was to buffer both the economy and the budget from the impact of commodity price changes.

- $\quad$ Most funds combine savings and stabilization objectives, including Kiribati's Revenue Equalization Reserve Fund (RERF), the Compact Trust Funds (CTFs) of the Marshall Islands and Micronesia after FY2023, ${ }^{13}$ Palau’s CTF, Nauru’s Phosphate

\footnotetext{
${ }^{13}$ The CTFs of the Marshall Islands and of Micronesia operate only as savings funds until FY2023 (the expectation is for both countries to have assets that generate returns high enough to fully replace U.S. budgetary
} 
Royalties Trust Fund (PRTF), and the Trust Funds of Tonga and Tuvalu. For example, the articles of agreement establishing Tuvalu's fund describe the overarching goal of long-term saving in terms of the short- to medium-term benefits to the economy and the budget, including stabilization and enhancing the capacity of the government to receive and effectively utilize foreign assistance. The objective of Tonga' fund is to accumulate reserves for use in exceptional circumstances and for major development projects.

\section{B. Revenue Sources}

The main revenue sources of the PICs funds are non-renewable resources, windfalls, and donor grants (Appendix Table A.3). Funds originally financed from non-renewable revenue sources include Kiribati and Nauru (both with phosphate revenue, which have since been exhausted in Kiribati, while Nauru is aiming to re-exploit some of its old mines), Papua New Guinea (with mineral revenue until the closure of the fund in 2001), and Timor-Leste (with petroleum revenue). Savings from windfall revenue were used to finance the Tonga and Tuvalu funds (in Tonga's case, mainly from the sale of passports to foreigners and the leasing of satellite space). Foreign donors have increasingly viewed sovereign wealth funds as a means of helping aid-dependent PICs to achieve fiscal sustainability. The first fund financed in this way was Tuvalu's; it was established in 1987 with contributions from windfall revenue and ad hoc donor assistance (mainly, the depositing of under-spending from the Australian bilateral aid program). The United States also agreed to set up SWFs with countries it formerly administered, the first of which was with Palau in 1994 under the Compact of Free Association agreement, followed in 2004 by the Marshall Islands and Micronesia (under a Compact II agreement); the Marshall Islands and Micronesia also contributed to the initial capital of their CTFs. Investment income from the assets is reinvested in the funds.

\section{Withdrawal Rules}

Some PICs (Timor-Leste, Papua New Guinea and Tuvalu) have anchored their fund's withdrawal rules in the concept of sustainable income in order to address long-term sustainability concerns, while allowing for some flexibility for stabilization purposes. For example, in Timor-Leste, withdrawals from the fund are linked to a sustainability benchmark for the non-oil deficit. Importantly, however, withdrawals can exceed the guideline with parliamentary approval, and thus the setup provides operational flexibility. Drawdowns from Papua New Guinea's stabilization fund were also supposed to be based on a medium-term perspective, while some flexibility was allowed for the Board and the Ministry of Finance to change the amounts under certain limits (Appendix Table A.3). Tuvalu eventually changed the design of its SWF's structure so as to address both its sustainability and stabilization needs (Box 1).

The Compact Trust Funds typically adopted more rigid rules with the expectation that the funds would, in the long term, be able to: (i) replace U.S. budgetary grants (presently

grants in FY2024). However, in principle, the authorities can make new deposits (in addition to the initial required deposit) in the CTFs and withdraw those funds at any time. 
accounting for over 50 percent of total revenue); and (ii) fulfill a stabilization objective. ${ }^{14}$ For example, the CTFs of the Marshall Islands and Micronesia do not allow disbursements prior to FY2023 and withdrawals are capped afterwards (Appendix Figure A.2). The CTF of Palau is less rigid, allowing withdrawals even during the asset accumulation phase, though these are capped at U.S.\$ 5 million inflation-adjusted per year until 2009. Once U.S. Compact grants cease in 2009, the Palau CTF is supposed to transfer to the budget a minimum of U.S.\$ 15 million inflation-adjusted per year.

Finally, some countries have opted for a discretionary approach to drawdowns (Kiribati, Nauru, and Tonga). Kiribati's drawdowns are at the discretion of the government, although it should take into account a guideline that calls for maintaining the 1996 real per capita value of the fund's assets constant. Withdrawals from Nauru's PRTF are at the discretion of its Board of trustees. The guidelines for withdrawals from Tonga's fund have not been made public, but when needed the government has been able to borrow from the fund.

\footnotetext{
${ }^{14}$ With these objectives in mind, the CTFs of the Marshall Islands and Micronesia consist of three accounts: a long-term savings account “A”, a buffer savings account “B”, and a disbursement account “C”. Initial contributions are deposited into, and investment income accrues to, account A. Investment returns in excess of 6 percent per year are deposited in account C, which will operate as a stabilization account from FY2024 onwards. This account is capped at three times the projected FY2024 transfer from the CTF needed to fully replace U.S. budgetary grants; overflows return to account A. Account B, which will only be created in 2022, will receive all previous year's investment income from account A, transfer to the budget an amount equal to the real value of FY2023 U.S. budgetary grants, then transfer any remaining funds, firstly to account C if it has not reached its cap, and secondly back to account A. In case account A investment income is insufficient to provide account B with the funds needed for the budgetary transfers, account $\mathrm{C}$ will be used.
} 


\section{Box 1. The Withdrawal Structure of Tuvalu's Sovereign Wealth Fund}

Tuvalu's fund structure has evolved over time and is fairly innovative. The fund was initially (1987) designed with a long-term sustainability in mind, but was felt to be paying insufficient attention to the stabilization needs of the budget (as the fund's volatile returns could not guarantee smooth and predictable transfers to the budget). As a result, in 1993 a stabilization account (account B-later transformed into the Consolidated Investment Fund (CIF)) was added to the savings account (account A-later called Tuvalu Trust Fund or TTF). Nowadays, the CIF is effectively an account of the government (Box Figure 1).

Recommended annual transfers from the TTF to the CIF are based on the difference between the TTF's market and the maintained values of its assets, where the latter is the real value of the opening annual balance of the TTF (using the Australian CPI as the deflator). The entire value of the CIF funds can be used by the ministry of finance at any point in time, although a guideline recommends that a target minimum balance (16 percent of the TTF's maintained value) be kept so as to ensure that a "sustainable TTF contribution" is available to help finance the budget at any given point in time. This is based on the assumption that the annual real rate of return on TTF's assets averages around 4 percent and that having a buffer of 4 years in the CIF (16 percent of TTF assets) will be enough to weather yearly volatility in financial returns.

The recommended structure would seem to allow for a considerable degree of flexibility for fiscal policy. Indeed, if the CIF met the minimum balance target, it would allow the budget to manage considerable shocks-amounting to a cumulative 48 percent of GDP over a four year period (a cumulative 16 percent of the TTF's assets of 300 percent of GDP) based on 2006 data. However, this flexibility is contingent on: (i) the government having a balanced overall fiscal position on average; and (ii) having the full 16 percent buffer in the CIF.

\section{Box Figure 1. Tuvalu Sovereign Wealth Fund Resource Flows}
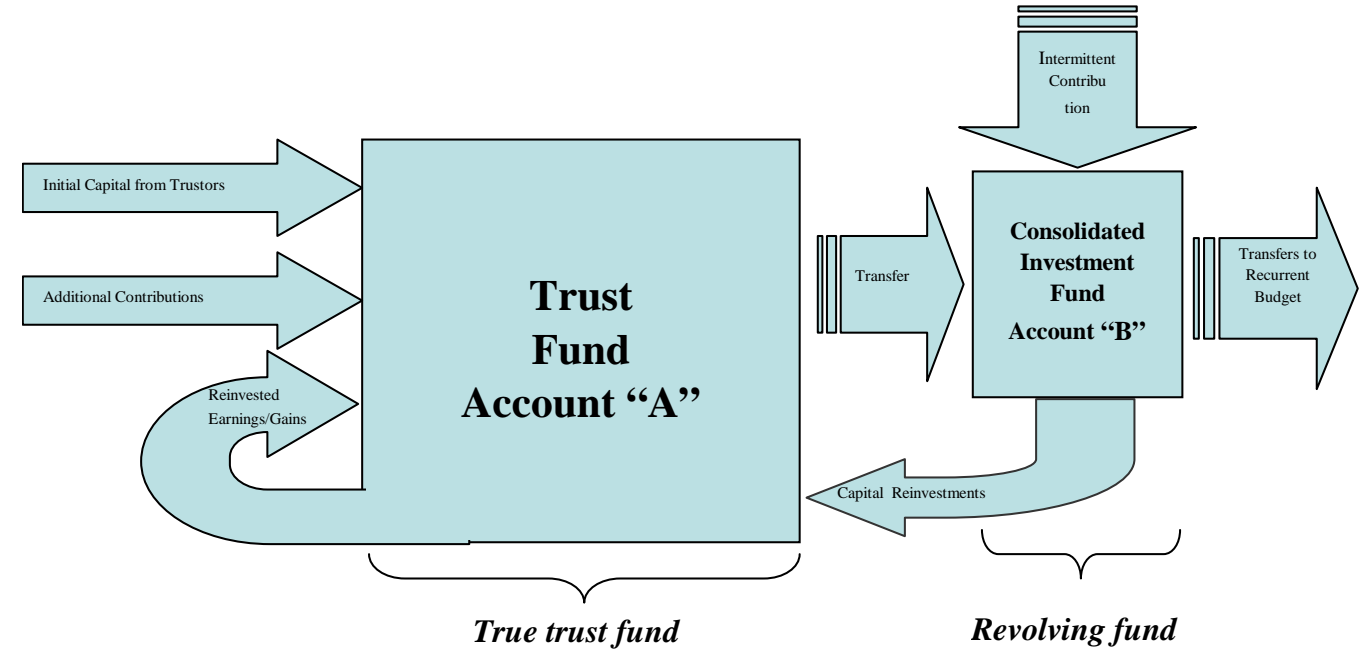

Figure source: Graham (2005) 


\section{Governance Structure}

Most PICs' sovereign wealth funds have a clearly defined governance structure. For example, the operations and management of Tuvalu's fund are specified in its articles of agreement, which detail the role and responsibilities of the board of directors, management, the advisory committee, and the monitoring and audit requirements. ${ }^{15}$ The funds of the Marshall Islands, Micronesia, and Timor-Leste have very similar governance structures except that they explicitly require independent and internationally reputable auditors. A few countries, however, have opted for less comprehensive specifications of the operations and management of their sovereign fund, or less transparency in describing these roles and responsibilities. For example, very little is publicly known about the operations and management of Nauru's Phosphate Royalties Trust Fund aside from having a board of directors comprised by senior government officials; similarly, all that is known about the Tonga fund is that it has a board of trustees consisting of the prime minister (chair), the minister of finance, and a royal appointee, and that investment and management decisions are made in consultation with the King.

Sovereign wealth funds in which donor financing is predominant are typically majoritycontrolled by the donors. These include the funds of the Marshall Islands, Micronesia, and Tuvalu, where the board of directors consists of representatives from the donors and the domestic authorities. In the case of the Tuvalu fund, the board typically is chaired by the minister of finance and the two other board members are appointed by the Australian and New Zealand governments. ${ }^{16}$ In the Marshall Islands, domestic representation consists of two out of seven board seats with the U.S. representative in the chair; and in Micronesia, the authorities have two of the five board member seats, with the U.S. representative also being the chair. In all three funds, each member has one vote and decisions are taken by majority vote. Palau is the exception with a donor-financed fund that is fully controlled by the domestic authorities; ${ }^{17}$ however, the rules of the fund impose strict withdrawal limits both during and after the period when the United States are contributing.

The governance structures also differ in the extent to which members of the board of directors, trustees, auditors, asset managers, and individuals working in the funds need to meet minimum requirements of expertise, professional background, and experience. The Marshall Islands, Micronesia, Timor-Leste, and Tuvalu are examples of funds with stringent requirements in these respects. ${ }^{18}$

\footnotetext{
${ }^{15}$ Responsibilities include advising the Tuvalu government on its budgets, assessing Tuvalu's economic development, and providing a recommendation to the Board on the size of any distribution from the TF to the budget.

${ }^{16}$ A fourth board member, from the United Kingdom, existed until 2003, when the U.K. withdrew from the rank of donors. The European Union has an observer status at the board in recognition of its indirect TF contribution.

${ }^{17}$ Although the authorities have hired foreign managers to operate the fund, as in the other CTFs.

${ }^{18}$ For instance, for the CTFs, the trustee must: (i) be selected from among trust institutions organized in the United States, (ii) have a net worth in excess of $\$ 100$ million, (iii) have at least 10 years experience as a custodian of financial assets, and (iv) have experience in managing trust funds of at least \$500 million (GAO, 2007). Timor-Leste and Tuvalu require their advisory committees to include qualified economists and financial experts as members.
} 


\section{ASSESSMENT OF THE FundS’ EFFECTIVENESS}

This section looks at how the various sovereign wealth funds have performed with respect to their original objectives and their impact on fiscal outcomes. It also provides a qualitative assessment of whether the funds have contributed to improved fiscal and asset management in the PICs by looking at key aspects of the fund design and integration with the budget process (Box 2 provides a brief survey of the broader international experience with resource funds).

\section{A. Did the Funds Achieve Their Objectives?}

Some countries have been able to accumulate significant fiscal savings in their funds based on sound fiscal policies. Timor-Leste, a new oil producer, has accumulated substantial assets in its Petroleum Fund as oil revenue has surged. The accumulation of assets also reflects the overall policy framework's orientation toward ensuring long-term sustainability, and capacity constraints that have kept spending below estimated sustainable levels. ${ }^{19}$ Kiribati's RERF also accumulated substantial savings in its early decades thanks to sound fiscal policies, but more recently has run down its assets as withdrawals from the fund have financed an expansionary fiscal policy and contributed to higher spending volatility (Box 3). While the assets of the fund remain sizable, the present trend could be unsustainable, particularly if the steadily declining non-tax revenue (mainly fishing rights) proves to be permanent. ${ }^{20}$

The experience of sovereign wealth funds created to help reduce future dependence on aid has produced mixed results. In general, donors have agreed to contribute to funds with the objective that PICs will gradually advance towards budgetary self-reliance. However, while the funds have been relatively successful in accumulating assets, their performance in helping achieve key policy goals has been weaker:

- $\quad$ Even with the creation of a second fund (CIF) for stabilization purposes, Tuvalu's SWF has had limited impact in shielding the budget from the volatility in revenue (Boxes 1 and 3). In part, this is a reflection of the rigid rules of the TTF, but also of the fact that the assets in the CIF were not large enough to have a significant impact

\footnotetext{
${ }^{19}$ A key element under Timor-Leste's existing fiscal framework is to ensure a long-term sustainable fiscal position, by setting as a guideline the principle that the non-oil deficit should be consistent with the estimated permanent income from oil wealth (net of government debt).

${ }^{20}$ As shown in Appendix Table A.2 in recent years, Kiribati’s deficit has averaged above 30 percent of GDP a year, financed not only by withdrawals from the RERF, but also depletion of cash reserves outside the fund. Crowe (2007) estimates that the large fiscal deficits may not be consistent with preserving the real per capita value of its RERF, and could lead to the depletion of the fund's assets.
} 


\section{Box 2. International Experience with Non-Renewable Resource Funds 1/}

The evidence suggest that resource funds have had limited impact in influencing fiscal outcomes and, if poorly designed, can actually hamper fiscal management. The cases where funds have been more successful are the ones integrated in sound fiscal frameworks and good institutions. In addition, the international experience with resource funds provide lessons on key aspects when designing a fund:

Flexible operational rules are usually preferable. While many countries have rigid deposit/withdrawal rules (e.g. share of oil revenue accrues to the fund, or a commodity pricebased rule), it is in general difficult to design a rule that can withstand time and wide variations in the commodity price or revenue. In many cases, as economic or political circumstances change, countries have searched for flexibility by changing, bypassing or eliminating the rules. In several cases, the operational rules of the funds are changed, e.g. the reference price or the revenue base, to adjust for budget needs. In some cases, the funds itself were abolished (Chad, Ecuador, Papua New Guinea).

Integration with the budget systems. The experience points to some key lessons as to whether funds can help or hinder the budget process.

- Earmarking and extrabudgetary spending. Countries have faced problems when earmarking the revenues in the fund, even if to protect priority areas, and/or allowing funds to spend outside the budget process. As resources are being pre-assigned and/or allocated outside the budget process it (i) reduces flexibility to adjust to changing conditions or priorities; (ii) complicates liquidity management; and (iii) affect the efficiency of government spending - by reducing competition for resources between different priorities and needs. In addition, the rules could create further fiscal pressures as the government may have to increase borrowing to finance other budgeted (priority) spending.

- Cash management. Rigid rules and fragmentation of cash management can complicate asset and liability management. For example, rigid rules in some countries resulted in the need for costly borrowing to make deposits in the funds.

- $\quad$ Financing funds (Norway, Timor-Leste) tend to be preferable, as they allow for great flexibility and are fully integrated with the budget, as the fund is designed to finance the budget as needed.

Asset management. In general few countries have a comprehensive and transparent investment strategy. In some cases this has resulted in the accumulation of assets being matched by large accumulation of debt. In general, resource funds tended to keep most assets invested abroad, mainly to allay fears about appreciation of the currency.

Transparency and accountability. The oversight of oil funds varies substantial around countries, including on provisions for compliances by government, audit of the accounts of the fund, and standards for disclosure of information. The degree of transparency also varies, with some countries providing detailed information on operations and assets of the fund (Norway is usually seen as the most transparent), while others provide very limited information.

1/ This analysis is primarily based on Davis et. al. (2003) and IMF (2007). 
on the budget. ${ }^{21}$ At the same time, fiscal policy has not been geared towards saving enough windfall revenue in the CIF, as recommended in the guidelines, to help manage revenue downturns. As a consequence, the mechanism used to finance the deficits has included short term borrowing from the national bank, debts to state owned enterprises, and arrears-Tuvalu has no domestic market for public bills and has no registry of external debt.

- $\quad$ The Marshall Islands and Micronesia Compact Trust Funds will need to be complemented by significant fiscal efforts to achieve the goal of long-term budgetary self-sufficiency. Under the Compact agreements with the U.S., grants to the budget will decline over time (requiring compensatory fiscal measures), and after 2023 are to be replaced by annual contributions from the funds (projected at the level of 2023 grants in real terms). Recent estimates indicate that the funds may not be able to provide these levels of returns and transfers to the budget. This would mean further fiscal tightening over the medium- to long-term and raises concerns as to whether the funds will be able to provide a stabilization mechanism as intended-something which depends on having rates of return beyond a defined benchmark (Baig, 2004; Faulkner-MacDonagh, 2007; GAO, 2007).

- In Palau, the CTF was expected to accumulate enough assets that the authorities would be able to disburse U.S.\$ 15 million every year (adjusted for inflation) starting in 2010 when the compact grants cease, while maintaining the real value of the assets. However, given the current heavy dependence on foreign aid, a substantial fiscal effort would still be required to ensure a sustainable fiscal position after $2009 .^{22}$ Otherwise, the CTF could be depleted in less than 15 years, as withdrawals will likely be significantly higher than the financial returns on the assets of the fund (Abdelati 2006). This reflects the overoptimistic returns on income envisaged at the time the fund was created and the high dependence on grants just to cover current spending, in spite of the authorities' efforts. The authorities are now seeking to renew the compact.

In a few cases, the funds have been almost depleted or closed. In large measure, the disappointing performance of the PNG and Nauru funds was related to inconsistency between the objectives of the funds and the fiscal policies being followed. In particular, in some countries, the accumulation of assets in the funds was being accompanied by unsustainable large fiscal deficits and rising public debt.

\footnotetext{
${ }^{21}$ Only in recent years have the transfers from the TTF to the CIF (to finance the budget) become significant as a share of total revenue.

${ }^{22}$ In addition, at present levels of the CTF assets, it is unlikely that the fund could generate \$15 million per year permanently.
} 


\section{Box 3. Expenditure Volatility in the Pacific Island Countries}

As the region with some of the highest revenue volatility, a key priority for fiscal policy should be to protect the budget from such volatility. In particular, countries may prefer to smooth spending and avoid costly and harmful disruptions in public services delivery and investment. In practice, PICs have, on average, not only been unable to limit the volatility in expenditure, but, in some cases, expenditure volatility has even exceeded revenue volatility (see table below).

While sovereign wealth funds could, in principle, be useful as a stabilization mechanism, they do not seem to have had a clear impact on expenditure volatility. Countries that successfully contained expenditure volatility have done so based on sound fiscal policies:

- $\quad$ In Kiribati, expenditure volatility has exceeded that of revenue reflecting mainly the sharp rise in expenditure in 2001-2004 (partly financed by large drawdowns from the fund). This large increase in expenditure, at a time of steady decline in fishing receipts has raised concerns regarding the sustainability of such policy. In Tuvalu there have also been concerns with the ability of the TTF to provide a stabilization mechanism; particularly as expenditure remains almost as volatile as revenue. A recent study by the TTF Advisory council (TTFAC, 2006) suggests the TTF may have contributed to higher expenditure volatility (expenditure reacts to the size of TTF disbursements). In addition, weak spending controls are likely to prevent a more cautious fiscal stance in periods of windfalls.

- $\quad$ In Samoa, after 1994, once the fiscal adjustment started, volatility has declined and expenditures have become less volatile than revenue. In Timor-Leste, where the SWF has been part of a broad strategy to ensure a sound and sustainable fiscal policy, the authorities have been able to limit the impact of volatile revenue on the budget.

Box Table 1. Volatility of Government Revenue and Expenditure, 1990-2005

\begin{tabular}{|c|c|c|c|c|}
\hline \multirow[b]{3}{*}{ Pacific Islands } & \multicolumn{2}{|c|}{ Standard deviation } & \multicolumn{2}{|c|}{ Coefficient of variation } \\
\hline & \multicolumn{2}{|c|}{$\begin{array}{l}\text { Revenue Expenditure } \\
\text { (as share of GDP) }\end{array}$} & \multirow{2}{*}{$\begin{array}{r}\text { Revenue } \\
0.07\end{array}$} & \multirow{2}{*}{$\begin{array}{r}\text { Expenditure } \\
0.10\end{array}$} \\
\hline & 4.0 & 6.0 & & \\
\hline Cook Islands & 4.0 & 7.4 & 0.11 & 0.16 \\
\hline Fiji Islands & 2.7 & 2.3 & 0.10 & 0.08 \\
\hline Kiribati & 24.0 & 31.8 & 0.21 & 0.25 \\
\hline Marshall Islands & 15.6 & 18.5 & 0.22 & 0.28 \\
\hline Micronesia & 14.3 & 12.5 & 0.19 & 0.16 \\
\hline Nauru 1/ & 33.9 & 51.7 & 0.44 & 0.45 \\
\hline Palau 2/ & 33.1 & 5.3 & 0.54 & 0.08 \\
\hline Papua New Guinea & 2.4 & 2.2 & 0.08 & 0.07 \\
\hline Samoa & 10.0 & 15.5 & 0.24 & 0.33 \\
\hline Solomon Islands & 11.5 & 10.7 & 0.36 & 0.27 \\
\hline Timor Leste 3/ & 53.6 & 4.3 & 0.88 & 0.21 \\
\hline Tonga & 2.4 & 3.5 & 0.08 & 0.11 \\
\hline Tuvalu & 51.2 & 41.4 & 0.48 & 0.40 \\
\hline Vanuatu & 2.0 & 4.5 & 0.09 & 0.17 \\
\hline
\end{tabular}

Source: staff estimates

1/ Refers to 1996-2001.

2/ The large revenue volatility reflects a one-time advance on grants from the US in 1995.

3/ Timor-Leste figures are in percent of non-oil GDP and refer to 2002-05. 
- $\quad$ In PNG, during the 1990s, while assets were being accumulated in the MRSF (from 3 percent of GDP in 1990 to almost 9 percent of GDP in 1998), public debt soaredrising by more than 30 percentage points of GDP over the same period. In addition, the assets of the fund were being used as collateral for new borrowing. By 1999, the authorities decided to use the assets in the MRSF to repay (expensive) debt and subsequently closed the fund.

- In several cases the operational rules of the funds were breached or changed to accommodate budgetary pressures (PNG, Tonga). For example, in PNG, rules on both accumulation and withdrawals were changed over time to give more flexibility in allocating commodity revenue. Furthermore, the Nauru and Tonga funds have been almost depleted due to risky investment decisions and mismanagement, as well as the financing needs of the budget. ${ }^{23}$

\section{B. A Qualitative Assessment}

\section{Integration with the budget process}

Of the funds examined in this paper, those of Timor-Leste and Kiribati are the most integrated with the budget. In Timor-Leste the fund works as a financing fund, integrated into a broader fiscal framework. Under the existing framework, the fund is to be used to finance the non-oil balance, which should be consistent with a long-term sustainable benchmark. ${ }^{24}$ On the other hand, the operations of most other funds in the Pacific islands have complicated the budget process. In most countries, the accumulation of assets in funds has contributed to a depletion of usable cash reserves and the need to borrow. In addition, some of the problems have been exacerbated by broader public financial management (PFM) system weaknesses and capacity constraints (Box 4).

- In several cases, relatively rigid withdrawal rules have contributed to the need for expensive short-term debt and/or arrears (e.g., Palau, Tuvalu). The budget operations and effective cash management have also been hampered by weaknesses in PFM and the dispersion of cash reserves among different funds/accounts (e.g., Tuvalu, PNG). ${ }^{25}$ The advisory committee of the Tuvalu fund has stressed the need to ensure overall

\footnotetext{
${ }^{23}$ The Tonga government sued an investment manager of its fund and, after a settlement, managed to receive a marginal compensation. The value of Nauru's NPRT assets is reported to have decrease by more than 90 percent between 1991 and 2006. In part it reflected the sale of real estate to repay public debt. The authorities expect that the Nauru fund will have a residual value of around $\mathrm{A} \$ 60$ million following the end of the receivership process currently under way. The Government of Nauru is developing a new trust arrangement to replace the NPRT and is also considering the creation of a separate national trust fund to hold government revenues with a goal similar to that of Tuvalu's TTF.

${ }^{24}$ The authorities can deviate from the benchmark, but need to explain the reasons to parliament.

${ }^{25}$ In PNG, while the fund closed in 2001, cash management problems and overall PFM weaknesses remain and the country continued to have deposits earmarked for projects while borrowing expensively to finance the deficit. However, in recent years, the fiscal position has improved and the authorities have started to reduce public debt.
} 


\section{Box 4. State of Public Financial Management in Selected PICs ${ }^{1 /}$}

Public Financial Management (PFM) systems are generally weak among PICs. ${ }^{2 /}$ Although countries, sometimes with donor participation, have attempted to design sovereign wealth funds that do not share the country's PFM weaknesses, these weaknesses nonetheless have a bearing on the overarching goal of SWFs (such as helping to foster fiscal sustainability ${ }^{3 /}$ ). PFM tends to be particularly weak in terms of comprehensiveness and transparency, and budget cycles. Comprehensiveness and transparency problems are especially acute, generally speaking, in the areas of (i) oversight of aggregate fiscal risk from other public sector entities (e.g., Kiribati); and (ii) the extent of unreported government operations (e.g., PNG, Tuvalu, and Vanuatu). Public access to key fiscal information is generally weak. Detailed PFM problems include the following:

- $\quad$ Policy-based budgeting is especially poor with regard to maintaining a multi-year perspective in fiscal planning, expenditure policy, and budgeting (e.g., PNG, Samoa, Tuvalu, and Vanuatu). SWFs' management is complicated when fiscal policy planning often does not extend beyond the current fiscal year (e.g., Tuvalu, TTFAC (2006)).

- $\quad$ Predictability and control in budget execution is poor for all the sampled PICs, something which has consequences for SWFs (e.g., countries with strict withdrawal rules and poor cash management have had to rely on expensive short-term borrowing or running arrears to meet temporary cash shortfalls despite having large assets accumulated in their TFs-these countries include the Marshall Islands and Tuvalu). Kiribati and Tuvalu highlight the importance of having a comprehensive approach to fiscal policy. Both countries have set up funds that are, overall, well-designed and have accumulated significant assets. However, both countries perform poorly in recording and managing cash balances, debt and guarantees (e.g., no public debt data are available). It is therefore difficult to assess whether the countries' current fiscal policies are adequate.

- $\quad$ Accounting, recording and reporting is very weak overall. Of particular concern are the quality and timeliness of in-year budget reports and annual financial statements.

- $\quad$ External scrutiny and audit is also very weak overall. A poor level of external scrutiny and audit in the central government often translates into a similarly poor actual record in other public entities, including SWFs.

1/ This box derives mainly from the Public Expenditure and Financial Accountability reports of PNG, Samoa, Tuvalu, and Vanuatu, and from ADB’s 2006 Country Strategy and Program Update on Kiribati.

2/ Interestingly, Samoa, as part of its fiscal reforms, has significantly improved its PFM systems so as to better manage macroeconomic shocks, among other benefits.

3/ For instance, the effectiveness of a sovereign fund will be hampered if the government is not able to timely and adequately know basic information such as its cash needs, progress in spending its budgetary commitments, level of arrears, or debt levels and forthcoming commitments. 
consistency between the operations of the Fund and fiscal policy, including meeting several sustainability benchmarks (TTFAC, 2006). ${ }^{26}$

- $\quad$ The Marshall Islands and Micronesia Compact funds operate outside of the budget, at least during the initial period of asset accumulation. Nevertheless, the requirement for the two countries to contribute to the funds at the outset has resulted in a significant reduction in usable cash reserves and new borrowing at a time when these countries are facing weak fiscal positions, including running payments arrears. ${ }^{27}$ For example, in 2006, the Marshall Islands authorities used assets provided by Taiwan to address a cash crisis (to pay for fuel supplies), although the assets were supposed to be accumulated for future needs and only used once the accumulated Taiwan grants had reached a minimum level. The Compact Funds have also generated further pressures on limited institutional capacity.

In general, the funds in the PICs have avoided extrabudgetary activities. In most cases, the funds are not allowed to spend, and are only used to finance the budget. However, in some cases the assets of the funds have been used as collateral for onlending or for granting loans with little or no oversight (Tonga, Marshall Islands, PNG, and Nauru). In addition, in many PICs quasi-fiscal and extra budgetary activities are carried out by other funds or public enterprises that are subject to limited controls or reporting.

\section{Asset management}

Some PICs' sovereign wealth funds have accumulated larger assets, as a share of GDP, than those of most other countries in the world (Table 1 ), ${ }^{28}$ although they are not always integrated in a broader asset-liability strategy. However, in several cases, the accumulation took place while the country was highly indebted, facing systematic deficits, or running budgetary arrears (Nauru, PNG, Marshall Islands, and Micronesia). In at least two cases, the assets of the funds were used as collateral to finance the fiscal deficit, resulting in one fund being closed (PNG) and another losing almost all its assets (Nauru). In the cases of the Marshall Islands and Micronesia, although both countries have accumulated significant assets in their Funds (Table 1), their Compact Agreements with donors prevent them from using these funds prior to 2024. At the same time both countries are running out of usable cash reserves and/or have difficulty in servicing debt.

\footnotetext{
${ }^{26}$ Tuvalu's fiscal guidelines require: (i) balanced budgets on average over the medium-term; (ii) budget deficits below 3 percent of GDP; (iii) assets in the CIF above 16 percent of the TTF's assets over any four-year period; (iv) drawdown from the CIF that is compatible with the TTF's sustainability; and (v) external debt below 60 percent of GDP. Most of the benchmarks have not been met, partly reflecting design issues with the targets and the high revenue volatility.

${ }^{27}$ In the case of the Federated States of Micronesia, the main source of immediate pressures is the finances of some of its states. The Marshal Islands has been unable to meet loan repayments to the Asian Development Bank since FY2006 - the ADB holds around 68 percent of the countries major liabilities (ADB, 2006).

${ }^{28}$ For example, according to a sample in IMF (2007), assets in oil funds are generally well below 100 percent of GDP, with the exception of Timor-Leste.
} 
PICs' investment strategies have varied, particularly regarding the level of exposure to risks. Some of the new funds (Timor-Leste, Marshall Islands, Micronesia ${ }^{29}$ ) have, in a first stage, adopted investment strategies that are similar to those followed to manage foreign exchange reserves that are kept for prudential reasons. ${ }^{30}$ This approach, also used by other countries, is likely to be preferable at the early stages of SWF implementation, as institutional capacity and experience are still limited and assets are at relatively low levels. Nevertheless, this raises the issue of whether the benchmarks for returns on assets used in some funds were too ambitious. For example, in its first few years, the Marshall Islands' CTF earned an annual nominal return of over $3 \frac{1}{2}$ percent, which is lower than the 6 percent stated objective. The funds are now moving towards a more diversified portfolio as their experience and expertise increases (see below).

Table 1. Pacific Island Countries: Sovereign Wealth Funds' Assets and Public Debt Levels (as of end-2006, unless otherwise noted)

\begin{tabular}{|c|c|c|c|c|c|}
\hline \multirow{3}{*}{ Country } & \multicolumn{3}{|c|}{ Sovereign Fund } & \multirow{2}{*}{\multicolumn{2}{|c|}{$\begin{array}{c}\frac{\text { Public Debt }}{\text { Value }} \\
\end{array}$}} \\
\hline & \multirow[t]{2}{*}{ Name } & \multicolumn{2}{|l|}{ Value } & & \\
\hline & & (in millions) & $\begin{array}{r}\text { (percent of } \\
\text { GDP) }\end{array}$ & (in millions) & $\begin{array}{r}\text { (percent of } \\
\text { GDP) }\end{array}$ \\
\hline Kiribati & Revenue Equalization Reserve Fund & A\$ 659 & 702 & A\$ 16 & 17 \\
\hline Marshall Islands & Compact Trust Fund & US\$ $631 /$ & 55 & US\$ 82 & 72 \\
\hline Micronesia & Compact Trust Fund & US\$ $871 /$ & 38 & US\$ 56 & 25 \\
\hline Nauru & Phosphate Royalties Trust Fund & In receivership 2/ & $\ldots$ & $A \$ 630$ & $\ldots$ \\
\hline Palau & Compact Trust Fund & US\$ $1523 /$ & 105 & US\$ 32 3/ & 24 \\
\hline Papua New Guinea & Mineral Resources Stabilization Fund & $\begin{array}{r}\text { Fund closed in } \\
2001\end{array}$ & $\ldots$ & US\$ 2,233 & 39 \\
\hline Timor Leste & Petroleum Fund & US\$ $9571 /$ & 225 & 0 & 0 \\
\hline Tonga & Tonga Trust Fund & US\$ $14 /$ & 0 & US\$ $1064 /$ & 47 \\
\hline Tuvalu & Tuvalu Trust Fund & A\$ 103 4/ & 300 & $\ldots$ & $\ldots$ \\
\hline
\end{tabular}

Source: IMF staff reports, Tuvalu Trust Fund reports, and country authorities.

$1 /$ As of September 30, 2006.

2/ The Fund is in receivership. The authorities expect the fund to retain assets worth A\$60 million or approximately 200 percent of GDP.

3/ As of end-2005.

4/ As of June-2006.

Others funds have adopted a more aggressive strategy based on investments in few assetse.g., Nauru's asset portfolio was mostly invested in lumpy real estate projects, while Tonga's portfolio consisted entirely of investments in three U.S. companies operating in the life insurance, energy, and internet businesses. The undiversified strategies used, together with mismanagement and the use of assets as a leverage for borrowing, resulted in large financial losses. These experiences illustrate the importance of ensuring that the asset management strategy for the SWF is consistent with the underlying policy objectives and the country's capacity to manage and monitor these investments.

\footnotetext{
${ }^{29}$ See GAO (2007) for a recent assessment of the funds’ performance.

${ }^{30}$ In general, assets have been invested in fixed-income instruments, such as U.S. Treasury bonds.
} 
Other funds have adopted a more diversified portfolio strategy resulting in average nominal returns of around 10 percent a year, although with relatively high volatility (Tuvalu ${ }^{31}$ and Palau). In both of these countries' sovereign wealth funds, the portfolio composition consists broadly of 66-70 percent in stocks and the remaining mostly in bonds. The Marshall Islands and Micronesia's CTF portfolios are now invested among a diversified pool of assets (across asset classes and geography) that consists of U.S. equities, international equities (for the Marshall Islands), U.S. bonds, U.S. real estates, and cash. For these sovereign funds, asset management performance (in terms of risk/returns) is evaluated against pre-determined benchmarks. $^{32}$

\section{Governance and transparency}

As discussed above, though the governance structures vary widely, there is typically only limited oversight and reporting of sovereign wealth fund activities. Only Timor-Leste and Tuvalu consistently publish annual reports. In spite of stringent quarterly reporting requirements for the Compact Trust Funds of the Marshall Islands and Micronesia, the experience to date is that these contain incomplete and unreliable information (GAO, 2007). ${ }^{33}$ Other funds (e.g., Kiribati, PNG, and Tonga) do not provide public information on a regular basis, and in most cases the information provided does not allow a proper assessment of fund performance. ${ }^{34}$ In the case of Nauru's PRTF, there is no mandated public disclosure of its investment strategy. Some of the problems in management and oversight are related to capacity constraints and the limited resources of the PICs. This is an area where donors could play a more active role in providing assistance and advice. In the case of Tuvalu, for example, the TTF's advisory committee provides not only an evaluation of the fund operations, but also broader economic advice, particularly on fiscal policy.

\footnotetext{
${ }^{31}$ Real annual returns (using the Australian CPI as a deflator) from 1988 to 2005 for Tuvalu's sovereign wealth fund ranged from -8.5 (in 2001) to 21.7 (in 1997) and averaged 6.3 percent but with a standard deviation of 8.6 percent (TTFAC, 2006). Management fees should be taken into account in assessing real returns as they can have a significant impact on long-term cumulative returns.

${ }^{32}$ In the case of Tuvalu's fund, the average real return of 6.3 percent compares favorably to (i) its 5-year performance benchmark of 4.5 percent; (ii) returns on 10-year Australian government bonds (4.6 percent); and (iii) investment in a 70/30 weighted portfolio of the Standard \& Poor's Australian Stock Exchange 200 index and 10-year Australian government bonds (5.9 percent). However, it underperforms, in terms of means, a portfolio that is 100 percent invested in the S\&P ASX 200 index (7.8 percent). Tuvalu's fund volatility has been on par with that of a portfolio consisting of 70/30 S\&P ASX 200 and 10-year Australian government bond.

33 There have been delays in setting up the funds, including selecting professional management, and in providing complete, audited, and timely reports as required by the Trust Fund agreements with the U.S.. In addition, under the agreement, a joint committee (U.S. and Marshall Islands/Micronesia) was supposed to assess the performance of the Fund vis-à-vis key policy objectives — this has not been done.
}

${ }^{34}$ For example, the Papua New Guinea’s MRSF net position was not known, as external borrowing using the MRSF assets as collateral was not fully disclosed. Tonga's TF financial transparency requirements were repeatedly not enforced, audits did not meet international standards, and no audit was published after 1999 (Jimenez de Lucio, 2003). 


\section{Conclusions And Policy Recommendations}

The experience shows that most of the Pacific Island countries will need to undertake structural reforms and large fiscal adjustments to improve economic prospects and reduce macro-fiscal vulnerabilities. Reaching budgetary self-reliance and a sustainable fiscal position will require addressing structural impediments to private sector growth, improving the quality of public institutions, and strengthening the fiscal position over the mediumterm. ${ }^{35}$ Sovereign wealth funds, if well designed, could be used as a tool to support a sound fiscal framework, but should not divert attention from the need to undertake key fiscal reforms.

The main potential benefits from the funds-namely protecting the budget from high revenue volatility and strengthening long-term fiscal prospects-have been hampered by a lack of integration with the budget, institutional weaknesses, and inadequate controls. As experiences in both the PICs and other countries reveal, accumulating revenues in a fund (and removing it from the budget) does not necessarily constrain the size or volatility of spending - unless there is a consistent overall fiscal framework. In some cases, accumulation of assets in the funds was accompanied by an accumulation of expensive debt or arrears. The weak performance of some of the funds has also been partly related to overall weaknesses in public financial management systems, including weak spending controls and cash managements. In some cases, the rigid operational rules of the funds have also hindered the countries' ability to respond to high revenue volatility and have hampered asset and liability management. The focus on achieving ambitious financial returns, together with weak governance, has led in some cases to risky investment profiles, mismanagement, and substantial losses in assets.

\section{A Reform Agenda}

Funds will only be effective in achieving their key goals if they are part of a sound fiscal policy framework (such as in Timor-Leste) and effective PFM systems. In several of the PICs this will require (i) better integrating the funds into the budget process; (ii) strengthening basic PFM systems_-including spending controls, cash management, and reporting; and (iii) developing institutional capacity, including preparing timely and reliable economic data essential for policy making and fiscal planning. In addition, the design of the funds will be key in ensuring they are helpful to fiscal management, in particular:

- $\quad$ Flexible operational rules (e.g., Timor-Leste, Kiribati) are preferable, as they facilitate the use of the funds for stabilization (a key objective in most PICs) and avoid the need for costly borrowing or arrears while accumulating assets in the funds. In addition they permit decision makers to adjust to changing policy priorities and circumstances. Nevertheless, it is important that (any) operational rules, to be effective, be consistent with sound policy objectives.

\footnotetext{
${ }^{35}$ Bertram (1986) argues that the small Pacific islands will likely always be dependent on capital inflows (remittances and foreign aid) and, as such, should not be trying to reach self-reliance. Nevertheless, even in cases where the islands are likely to remain to some degree dependent on aid, structural reforms and improved fiscal management could help improve growth prospects and reduce vulnerabilities.
} 
- $\quad$ Funds should not have authorization to spend on or be involved in extrabudgetary activities. This would ensure the integrity of the budget and allow greater consistency and transparency in conducting fiscal policy.

- $\quad$ Strengthening governance and transparency would contribute to greater accountability and ensure that public assets are well managed. ${ }^{36}$

Given the challenges facing the PICs, the analysis also suggests a need to better incorporate a long-term perspective into the budget process. While some funds were created to help address long-term sustainability concerns, they will not be effective if overall fiscal policies do not reflect those considerations. Integrating the annual budget in a sound medium-term fiscal framework (MTF), could help better link the annual budgets to the medium- to longterm challenges; identify long-term consequences of present policies; and build consensus for reforms. Conditional on institutional capacity, countries could gradually prepare and implement more comprehensive MTFs. ${ }^{37}$

Developing a MTF would also help identify key fiscal risks and improve the design of stabilization policies and tools, including sovereign wealth funds. Given the very high degree of volatility faced by PICs, preparing the annual budget based on sound MTFs, including an assessment of the key fiscal risks, would help improve fiscal planning and management. In particular, countries could better prepare for shocks by either addressing the sources of vulnerabilities - e.g., via structural reforms and fiscal adjustment (the choice made by Samoa)—and/or defining an appropriate level of savings for stabilization purposes.

The asset management of the sovereign fund should be integrated with the country's broader fiscal and asset management strategy. The choice of portfolio should be geared towards maximizing the (risk-adjusted) financial return, conditional on the underlying fiscal objectives (e.g., stabilization, long-term fiscal sustainability), and consistent with the broader strategy for asset-liability management. For example, assets kept for stabilization purposes should be invested in relatively liquid instruments. In addition, in cases where the budget is highly dependent on resources from the fund, it may be advisable to have a more cautious investment strategy. The assets could also be invested as part of a strategy to hedge against key sources of vulnerability (e.g., from commodity prices or the exchange rate) —although it may be preferable to have relatively conservative investment portfolios until sufficient capacity to assess risks is developed and appropriate safeguards are in place.

\footnotetext{
36 The IMF’s “Code of Good Practices on Fiscal Transparency” and the "Guide on Resource Revenue Transparency” provide guidelines on transparency regarding management of public assets, including resource funds - which, in general, can be applied to the sovereign wealth funds.

${ }^{37}$ The simplest form of MTFs is a medium-term fiscal framework (MTFF), which involves a statement of fiscal policy objectives, consistent medium-term macroeconomic projections, and setting aggregate fiscal targets with a view to ensure macro-stability and address long-term sustainability considerations. Even a simple MTFF can provide a framework to link long-term perspectives with the annual budgets and promote greater accountability. More advanced forms of MTFs include medium-term budget frameworks and medium-term expenditure frameworks. Both require greater capacity and fundamental changes in the way budgets are prepared. See IMF (2007) for more discussion on gradual implementation of different modalities according to capacity constraints.
} 


\section{REFERENCES}

Abdelati, W. F., 2006, “Palau: Future of the Compact Trust Fund,” Selected Issues Paper, IMF, Washington, D.C.

Asian Development Bank, 2006, “The Marshall Islands, 2007-2011”, ADB Country Strategy and Program Update, Manila, Philipines.

AusAID, 2005, “Evaluation of the Tuvalu Trust Fund,” AusAID, Camberra.

Baig, T., 2004, “Managing Financial Resources for Long-Term Sustainability,” Selected Issues Paper, IMF, Washington, D.C.

Barnett, J., 2001, “Adapting to Climate Change in Pacific Island Countries: The Problem of Uncertainty,” World Development, Vol. 29, pp. 977-93.

Barro, R., and X. Sala-i-Martin, 1995, Endogenous Growth Theory, McGraw-Hill, New York.

Bertram, G., 1986, “'Sustainable Development’ in Pacific Micro-economies,” World Development, Vol. 14, pp. 809-822.

Browne, C. (ed.), 2006, Pacific Island Economies, International Monetary Fund, Washington, D.C.

Crowe, C., 2007, “Kiribati: The Revenue Equalization Reserve Fund,” Selected Issues Paper, IMF, Washington, D.C.

Davis, J., R. Ossowski, J. Daniel, and S. Barnett, 2003, “Stabilization and Savings Funds for Nonrenewable Resources: Experience and Fiscal Policy Implications”, in Davis et al., Fiscal Policy Formulation and Implementation in Oil-Producing Countries, Chapter 11, pp. 273-315, IMF, Washington, D.C..

Davis, J., R. Ossowski, and A. Fedelino (eds.), 2003, Fiscal Policy Formulation and Implementation in Oil-Producing Countries, IMF, Washington, D.C.

Easterly, W., and A. Kray, 2000, "Small States, Small Problems? Income, Growth, and Volatility in Small States,” World Development, Vol. 28, pp. 2013-27.

Faulkner-MacDonagh, C., 2007, “Strengthening Micronesia’s Compact Trust Fund,” Selected Issues Paper, IMF Washington, D.C.

Graham, B., 2005, “Trust Funds in the Pacific: Their Role and Future,” ADB Pacific Studies Series, Manila, Philippines.

IMF, 2007, “The Role of Fiscal Institutions in Managing the Oil Revenue Boom,” Washington, D.C.

Jimenez de Lucio, A., 2003, “Experience with the Tonga Trust Fund,” Selected Issues Paper, IMF, Washington, D.C. 
Johnson-Calari, J. and M. Rietveld (eds.), 2007, Sovereign Wealth Management, Central Bank Publications Ltd, United Kingdom.

GAO, 2007, "Compacts of Free Association: Trust Funds of Micronesia and the Marshall Islands May Not Provide Sustainable Income,” United States Government Accountability Office, Report to Congressional Committees No 07-513, June.

Purfield, C., 2005, "Managing Revenue Volatility in a Small Island Economy: The Case of Kiribati,” IMF Working Paper No. 05/154, Washington, D.C.

Rodrick, D., 1998, “Why Do More Open Economies Have Bigger Governments?” Journal of Political Economy, Vol. 106, pp. 997-1032.

TTFAC, 2006, “2006 Annual Report of the Tuvalu Trust Fund Advisory Committee”, Tuvalu, November 2006. 
Table A.1. Pacific Island Countries: Basic Geographic, Social, and Economic Indicators

\begin{tabular}{|c|c|c|c|c|c|c|c|}
\hline & $\begin{array}{l}\text { Population } \\
\text { (Thousands) }\end{array}$ & $\begin{array}{c}\text { Area } \\
\text { (In thousands } \\
\text { of square } \\
\text { kilometers) }\end{array}$ & $\begin{array}{c}\text { GDP } \\
2005 \\
\text { (US\$ millions) }\end{array}$ & $\begin{array}{c}\text { GDP } \\
\text { per capita } \\
2005 \text { (US\$) }\end{array}$ & $\begin{array}{c}\text { Main Current } \\
\text { Receipts } \\
\text { (Remittances } \\
\text { from private sector) }\end{array}$ & $\begin{array}{l}\text { Exchange } \\
\text { Rate } \\
\text { Regimes }\end{array}$ & $\begin{array}{l}\text { Aid per } \\
\text { Capita } \\
\text { (US\$) }\end{array}$ \\
\hline Cook Islands & 20 & 0.20 & 183 & 9,059 & $\begin{array}{l}\text { Tourism, pearls, fish, } \\
\text { fruits, textiles }\end{array}$ & $\begin{array}{c}\text { New Zealand } \\
\text { Dollars }\end{array}$ & 485 \\
\hline Fiji Islands & 850 & 18.27 & 2816 & 3,313 & $\begin{array}{l}\text { Sugar, textiles, } \\
\text { tourism }\end{array}$ & Basket peg & 75 \\
\hline Kiribati & 94 & 0.73 & 56 & 596 & $\begin{array}{c}\text { Fish licenses, } \\
\text { seamen remittances }\end{array}$ & $\begin{array}{l}\text { Australian } \\
\text { Dollar }\end{array}$ & 281 \\
\hline Marshall Islands & 55.3 & 0.18 & 138 & 2,495 & $\begin{array}{l}\text { Remittances from } \\
\text { the United States }\end{array}$ & U.S. Dollar & 894 \\
\hline Micronesia & 108.3 & 0.70 & 237 & 2,188 & $\begin{array}{l}\text { Remittances from } \\
\text { the United States }\end{array}$ & U.S. Dollar & 787 \\
\hline Nauru & 10 & 0.02 & 55 & 4,068 & Phosphate & $\begin{array}{l}\text { Australian } \\
\text { Dollar }\end{array}$ & 1022 \\
\hline Palau & 20 & 0.46 & 145 & 7,233 & Tourism & U.S. Dollar & 1167 \\
\hline Papua New Guinea & 5,887 & 452.86 & 4920 & 836 & $\begin{array}{l}\text { Oil, copper, gold, } \\
\text { coffee, cocoa }\end{array}$ & Managed Float & 45 \\
\hline Samoa & 185 & 2.83 & 340 & 1,838 & $\begin{array}{l}\text { Remittances from } \\
\text { New Zealand }\end{array}$ & Basket peg & 238 \\
\hline Solomon Islands & 478 & 27.99 & 298 & 623 & Timber, palm oil, fish & Basket peg & 415 \\
\hline Timor Leste & 983 & 14.87 & 350 & 356 & Oil, sandalwood & U.S. Dollar & 189 \\
\hline Tonga & 102 & 0.72 & 215 & 2,108 & $\begin{array}{l}\text { Remittances from } \\
\text { New Zealand }\end{array}$ & Basket peg & 310 \\
\hline Tuvalu & 10 & 0.03 & 26 & 2,709 & Seafarers remittances & $\begin{array}{l}\text { Australian } \\
\text { Dollar }\end{array}$ & 770 \\
\hline Vanuatu & 210 & 12.19 & 368 & 1,752 & Tourism & Basket peg & 187 \\
\hline
\end{tabular}

Sources: ADB; World Bank, 2005 World Development Indicators; United Nations. 
Table A.2. Pacific Island Countries: Central Government Fiscal Indicators (In percent of GDP) $1 /$

\begin{tabular}{|c|c|c|c|c|c|c|c|}
\hline & $\begin{array}{c}\text { 1990-1999 } \\
\text { (Average) 2/ }\end{array}$ & 2000 & 2001 & 2002 & 2003 & 2004 & 2005 \\
\hline \multicolumn{8}{|c|}{ Total revenue and grants (as share of GDP) } \\
\hline Pacific Islands & 54 & 63 & 50 & 53 & 50 & 54 & 58 \\
\hline Cook Islands & 37 & 31 & 32 & 30 & 28 & 28 & 35 \\
\hline Fiji Islands & 27 & 24 & 22 & 27 & 25 & 26 & 26 \\
\hline Kiribati & 105 & 104 & 128 & 149 & 155 & 147 & 133 \\
\hline Marshall Islands & 74 & 69 & 74 & 66 & 66 & 57 & 60 \\
\hline Micronesia & 83 & 66 & 64 & 72 & 69 & 59 & 57 \\
\hline Nauru & 71 & 99 & 79 & $\ldots$ & $\ldots$ & $\ldots$ & $\ldots$ \\
\hline Palau & 69 & 52 & 43 & 42 & 54 & 54 & 54 \\
\hline Papua New Guinea & 29 & 30 & 30 & 28 & 29 & 34 & 34 \\
\hline Samoa & 46 & 33 & 32 & 33 & 35 & 34 & 47 \\
\hline Solomon Islands & 29 & 22 & 24 & 19 & 39 & 48 & 66 \\
\hline Timor Leste 1/ & $\ldots$ & $\ldots$ & 15 & 24 & 31 & 98 & 137 \\
\hline Tonga & 30 & 28 & 29 & 31 & 28 & 30 & 29 \\
\hline Tuvalu & 98 & 243 & 124 & 152 & 71 & 66 & 58 \\
\hline Vanuatu & 23 & 21 & 20 & 22 & 20 & 22 & 22 \\
\hline \multicolumn{8}{|c|}{ Total expenditure and net lending (as share of GDP) } \\
\hline Pacific Islands & 60 & 65 & 58 & 53 & 54 & 54 & 52 \\
\hline Cook Islands & 54 & 35 & 37 & 36 & 33 & 32 & 40 \\
\hline Fiji Islands & 31 & 30 & 30 & 32 & 31 & 29 & 29 \\
\hline Kiribati & 111 & 106 & 146 & 150 & 189 & 199 & 157 \\
\hline Marshall Islands & 70 & 60 & 65 & 70 & 55 & 57 & 63 \\
\hline Micronesia & 86 & 75 & 70 & 64 & 68 & 66 & 62 \\
\hline Nauru & 122 & 105 & 90 & $\ldots$ & $\ldots$ & $\ldots$ & $\ldots$ \\
\hline Palau & 63 & 71 & 65 & 66 & 63 & 63 & 54 \\
\hline Papua New Guinea & 31 & 32 & 33 & 32 & 30 & 32 & 31 \\
\hline Samoa & 52 & 33 & 35 & 35 & 36 & 35 & 47 \\
\hline Solomon Islands & 39 & 32 & 36 & 30 & 39 & 40 & 64 \\
\hline Timor Leste 1/ & $\ldots$ & $\ldots$. & 14 & 20 & 20 & 21 & 26 \\
\hline Tonga & 32 & 29 & 27 & 32 & 31 & 29 & 27 \\
\hline Tuvalu & 97 & 210 & 142 & 97 & 87 & 73 & 61 \\
\hline Vanuatu & 28 & 29 & 25 & 26 & 21 & 20 & 20 \\
\hline \multicolumn{8}{|c|}{ Overall balance (as share of GDP) } \\
\hline Pacific Islands & -5.6 & -3 & -8 & -1 & -5 & -6 & -5 \\
\hline Cook Islands & -16.8 & -5 & -5 & -6 & -5 & -5 & -5 \\
\hline Fiji Islands & -3.5 & -6 & -8 & -6 & -6 & -3 & -4 \\
\hline Kiribati & -6.0 & -2 & -18 & -1 & -34 & -52 & -24 \\
\hline Marshall Islands & 3.7 & 8 & 9 & -4 & 11 & 0 & -4 \\
\hline Micronesia & -2.6 & -9 & -6 & 8 & 1 & -6 & -5 \\
\hline Nauru & -50.3 & -6 & -11 & $\ldots$ & $\ldots$ & $\ldots$ & $\ldots$ \\
\hline Palau & 6.6 & -19 & -22 & -28 & -2 & -7 & -3 \\
\hline Papua New Guinea & -2.3 & -1 & -4 & -5 & -2 & 0 & 4 \\
\hline Samoa & -6.0 & -1 & -2 & -2 & -1 & -1 & 0 \\
\hline Solomon Islands & -10.3 & -10 & -13 & -11 & 0 & 8 & 2 \\
\hline Timor Leste 1/ 3/ & $\ldots$ & $\ldots$ & -2 & -5 & -1 & 0 & -17 \\
\hline Tonga & -2.4 & -1 & 2 & -2 & -3 & 1 & 3 \\
\hline Tuvalu & 1.6 & 33 & -18 & 54 & -16 & -7 & -2 \\
\hline Vanuatu & -5.3 & -8 & -6 & -4 & -2 & 1 & 2 \\
\hline
\end{tabular}

Source: ADB, APD REO, IMF country documents, National authorities, and Fund staff estimates.

1/ Timor -Leste figures are in percent of non-oil GDP.

2/ For Nauru the average is from 1996-99

3/ Excluding oil revenue 
Table A.3. Operational Rules of Selected Pacific Islands Sovereign Wealth Funds

\begin{tabular}{|c|c|c|c|c|c|c|}
\hline Country & Name & $\begin{array}{l}\text { Date } \\
\text { established }\end{array}$ & Stated objectives & Revenue source & Withdrawal rules & Oversight and reporting \\
\hline Kiribati & $\begin{array}{l}\text { Revenue Equalization } \\
\text { Reserve Fund }\end{array}$ & 1956 & $\begin{array}{l}\text { Stabilization and savings. Maintain the } \\
1996 \text { real per capita value of the Fund } \\
\text { (guideline since 1996) }\end{array}$ & $\begin{array}{l}\text { e Phosphate revenue (exhausted in 1979), } \\
\text { budget surpluses, and investment income }\end{array}$ & Discretionary transfers to the budget & $\begin{array}{l}\text { Information on operations and balances (with lagss) is presented to } \\
\text { Parliament at the time of the budget. The government receives detailed } \\
\text { monthly statements but these are not public. }\end{array}$ \\
\hline Marshall Islands & Compact Trust Fund & 2004 & $\begin{array}{l}\text { Help achieve budgetary self-reliance } \\
\text { as US grants to the budget set to } \\
\text { expire by } 2023 \text {. }\end{array}$ & $\begin{array}{l}\text { Mainly US grants along with a Marshall } \\
\text { Island initial contribution. Taiwan agreed } \\
\text { in May } 2005 \text { to provide US } \$ 40 \text { million in } \\
\text { contributions to the Fund }\end{array}$ & $\begin{array}{l}\text { In } 2024 \text { and thereafter, the income revenue from the } \\
\text { previous year can be transferred up to a limite equivalent to } \\
\text { the annual grant assistance in } 2023 \text { (in real terms). Prior to } \\
2022 \text { no disbursement is allowed and the Fund's assets } \\
\text { cannot be used as collateral. }\end{array}$ & $\begin{array}{l}\text { there is a trustee to collect funds, manage the disbursement, and act as a } \\
\text { day-to-day overseer and an independent auditor. Publication of annual } \\
\text { reports to the government and the United States within } 6 \text { months after the } \\
\text { end of each fiscal year, they should contain audited account information } \\
\text { and the audit reports. }\end{array}$ \\
\hline Micronesia & Compact Trust Fund & 2004 & $\begin{array}{l}\text { Help achieve budgetary self-reliance } \\
\text { as US rgants to the budget set to } \\
\text { expire by 2023. }\end{array}$ & $\begin{array}{l}\text { US grants (grants are increasing over a } 20 \\
\text { year period dfter which they stop) along } \\
\text { with a contribution from Micronesia. }\end{array}$ & $\begin{array}{l}\text { In } 2024 \text { and thereafter, the income revenue from the } \\
\text { previous year can be transferered up to a limite equivialent to } \\
\text { the annual grant assistance in } 2023 \text { (in real terms). Prior to } \\
2024 \text { no disbursement is allowede and the Fund's assets } \\
\text { cannot be used as collateral. }\end{array}$ & $\begin{array}{l}\text { there is a trustee to collect funds, manage the disbursement, and act as a } \\
\text { day-to-day overseer and an independent auditor. Publication of annual } \\
\text { reports to the government and the United States within } 6 \text { months after the } \\
\text { end of each fiscal year; they should contain audited account information } \\
\text { and the audit reports. }\end{array}$ \\
\hline Nauru & $\begin{array}{l}\text { Phosphate Royalties Trust } \\
\text { Fund }\end{array}$ & 1968 & $\begin{array}{l}\text { Long-term fiscal sustainability in } \\
\text { anticipation of the exhaustion of } \\
\text { phosphate resources }\end{array}$ & Phosphate revenue & At the discretion of the Board of Trustees. & $\begin{array}{l}\text { Reports were limited to a few senior officials. No public disclosure of the } \\
\text { investment strategy or the operations of the Fund. }\end{array}$ \\
\hline Palau & Compact Trust Fund & 1994 & $\begin{array}{l}\text { Help achieve budgetary self-reliance } \\
\text { as US grants to the budget set to } \\
\text { expire by } 2009 \text {. }\end{array}$ & US grants & $\begin{array}{l}\text { Withdrawals of up to US\$5 million inflation-adjusted per } \\
\text { year from } 2000 \text { to } 2009 \text {; and USS15 million inflation- } \\
\text { adjusted per year from } 2010 \text { onwards. }\end{array}$ & $\begin{array}{l}\text { Investment strategy, reporting, internal and external audit, and } \\
\text { withdrawal authorization are governed by legislation. Annual public } \\
\text { reports to the President, Congress, and the Public Auditor. }\end{array}$ \\
\hline Papua New Guinea & $\begin{array}{l}\text { Mineral Resources } \\
\text { Stabilization Fund }\end{array}$ & $\begin{array}{l}1974 \text { (closed in } \\
2001)\end{array}$ & n Stabilization & Mineral revenue & $\begin{array}{l}\text { The managers of the fund provide recommendations on the } \\
\text { annual levels of disbursements that are sustaianable for five } \\
\text { years. The board's recommendation on the amounts to be } \\
\text { transferred to the budget would not vary by more than } 20 \\
\text { percent, although the Minister of Finance had the option to } \\
\text { vary the amounts by an additional } 10 \text { percent. }\end{array}$ & $\begin{array}{l}\text { The budget documents contain a summary table of changes in the } \\
\text { balance of the MRSF. Also, the central bank's Quarterly Economic } \\
\text { Bulletin provides details of movements in the MRSFF. The final accounts } \\
\text { contain a detailed statement of the government's equity investments. }\end{array}$ \\
\hline Timor Leste & Petroleum Fund & 2005 & $\begin{array}{l}\text { Promote long-term fiscal sustainability } \\
\text { and inter-generational equity. }\end{array}$ & $\begin{array}{l}\text { y All petroleum revenue (i.e., includes } \\
\text { revenue emanating directly or indirectly } \\
\text { from petroleum resources) and investment } \\
\text { income }\end{array}$ & $\begin{array}{l}\text { Withdrawals from the Fund can exceed a "ustainable } \\
\text { income" (as defined by law) under certain conditions and } \\
\text { subject to Parliamentary approval. Total transfers in a fiscal } \\
\text { year cannot exceed a ceiling set by parliament as part of the } \\
\text { approval of the budget. }\end{array}$ & $\begin{array}{l}\text { Annual audits by internationally recognized firms. Investment } \\
\text { performance periodicallly assessed by external experts. Oversight bodies } \\
\text { monitor operations. Mandated frequent disclosure and reporting, } \\
\text { including as part of the annual budget; quarterly financial statements are } \\
\text { published. }\end{array}$ \\
\hline Tonga & Tonga Trust Fund & 1988 & $\begin{array}{l}\text { Accumulate reserves for use in } \\
\text { exceptional circumstances and for } \\
\text { major development projects }\end{array}$ & $\begin{array}{l}\text { Sale of Tongan passports to foreigners; } \\
\text { revenue from lease of Tongan satellite } \\
\text { space }\end{array}$ & Unknown & $\begin{array}{l}\text { Required by law to provide annual financial statements and the Auditor } \\
\text { Genenar's report to parliament and the public. No audits have been } \\
\text { published after } 1999 \text {. }\end{array}$ \\
\hline Tuvalu & $\begin{array}{l}\text { Tuvalu Trust Fund (since } \\
1993 \text {, the fund contains two } \\
\text { accounts, one for } \\
\text { stabilization and one for long } \\
\text { term savings, in 2002 these } \\
\text { become two separate funds: } \\
\text { the CIF and the TTF, } \\
\text { respectively) }\end{array}$ & 1987 & $\begin{array}{l}\text { Maintain the real value of the fund's } \\
\text { principal in perpetuity (using the } \\
\text { Australian CPI). Help smooth } \\
\text { budgetary revenue volatility. }\end{array}$ & $\begin{array}{l}\text { Donors and Tuvalu transfers to the TTF. } \\
\text { Since creation of second fund, CIF, these } \\
\text { receives transfers from TTF and windfall } \\
\text { revenue. }\end{array}$ & $\begin{array}{l}\text { A distribution from the Tuvalu Trust Fund to the CIF is only } \\
\text { possible when the market value of the fund exceeds the } \\
\text { maintained value, being the real value as measurued by the } \\
\text { Australian CCI. Withrawals from the CII are at discretion } \\
\text { of the Ministryy of Finance, athoughh there is a Tagret } \\
\text { Minimum Balance (16 percent of the maintained value of the } \\
\text { TTF). }\end{array}$ & $\begin{array}{l}\text { The Fund discloses financial information to Parliamentary and the } \\
\text { public. The Government annual budget report includes information on } \\
\text { the fund's performance and its year-end value. }\end{array}$ \\
\hline
\end{tabular}


Figure A.1. PICs: Revenue Volatility and Sovereign Wealth Funds, 1990-2004.

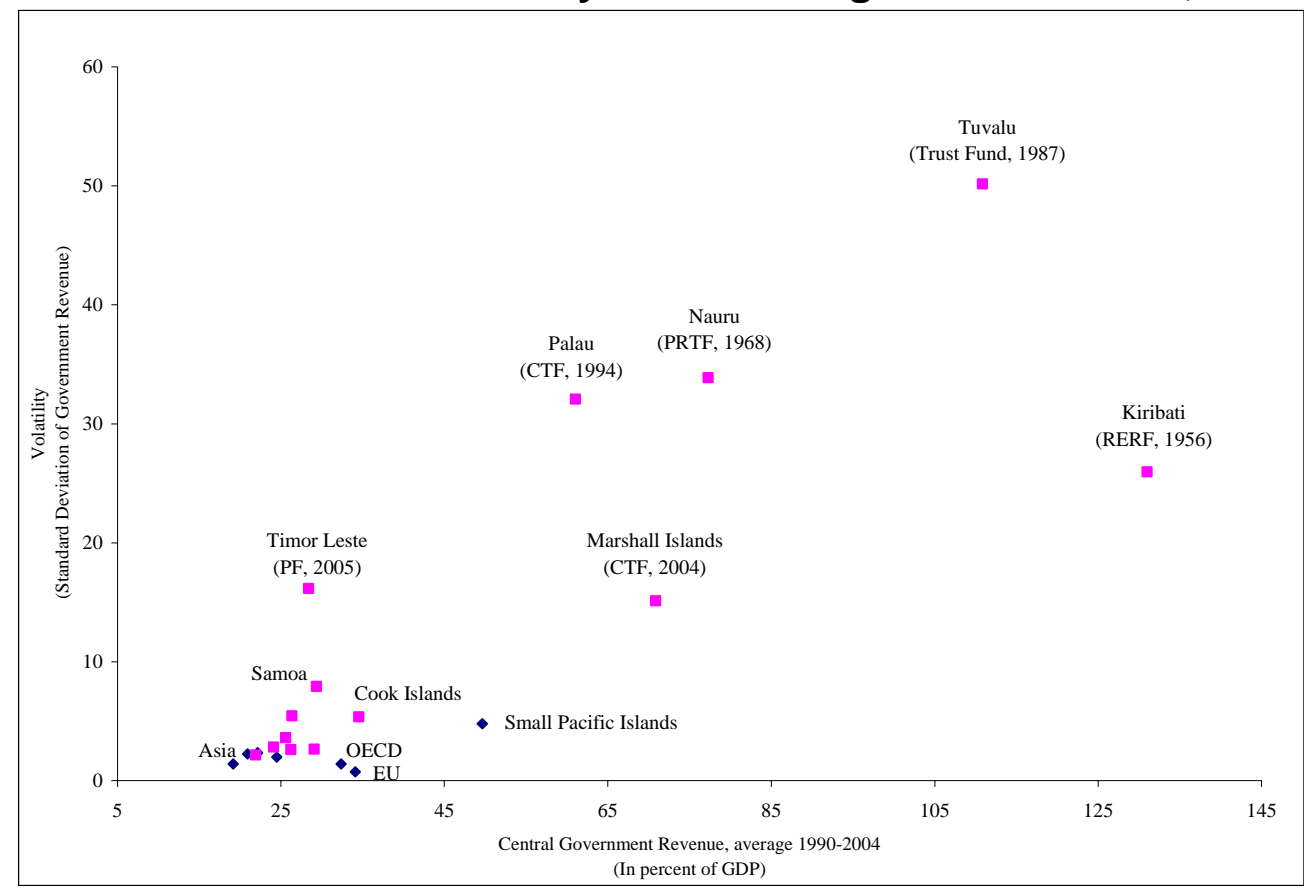

Source: ADB, IMF staff, national authorities.

Figure A.2. Structure of the Marshall Islands and Micronesia Sovereign Wealth Funds

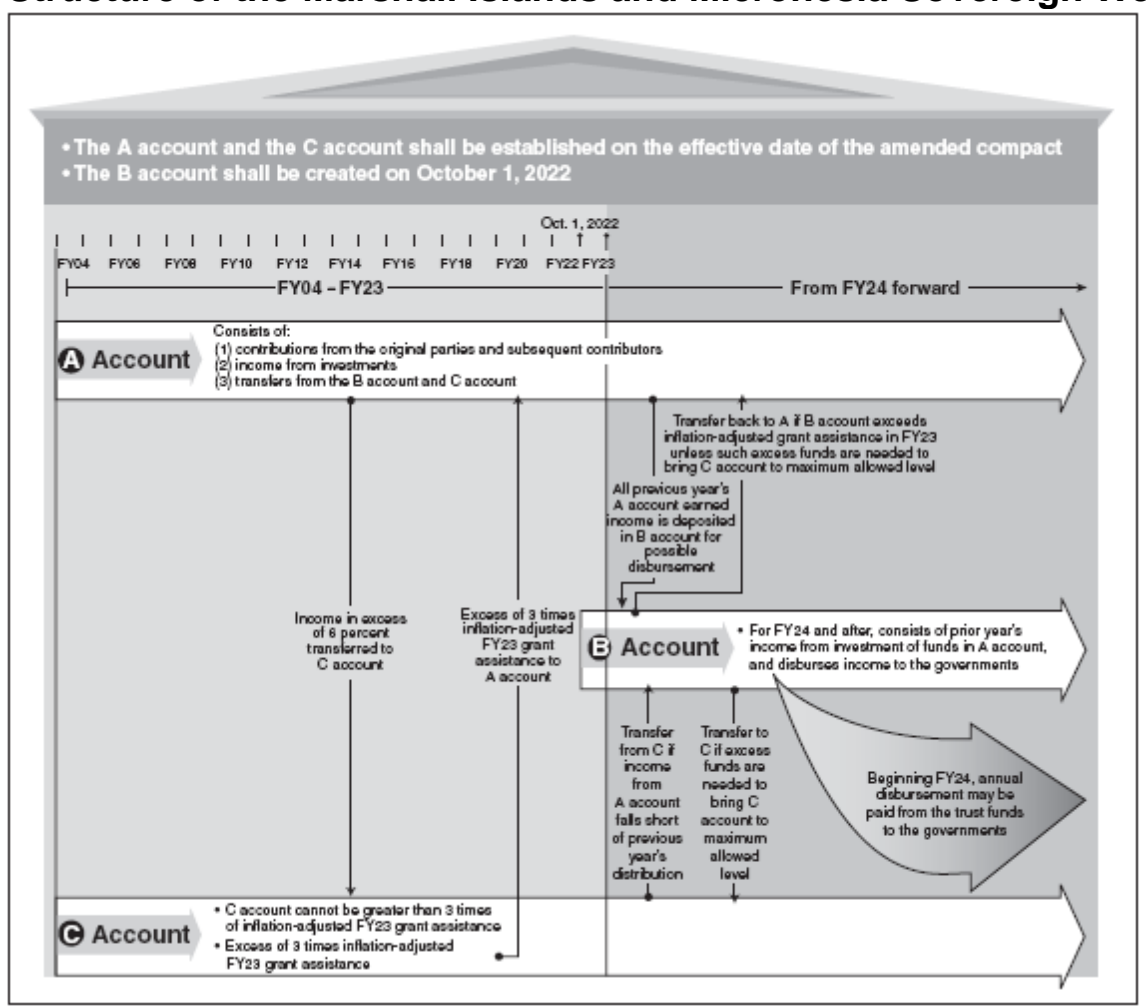

Source: GAO (2007). 